\title{
Assessment of Water Quality for Drinking Purpose in District Pauri of Uttarakhand, India
}

\author{
Shweta Tyagi ${ }^{1}$, Prashant Singh ${ }^{1}$, Bhavtosh Sharma ${ }^{2, *}$, Rakesh Singh $^{3}$ \\ ${ }^{1}$ Department of Chemistry, DAV (PG) College, Dehradun, Uttarakhand, India \\ ${ }^{2}$ Uttarakhand Science Education and Research Center (USERC), Dehradun, Uttarakhand, India \\ ${ }^{3}$ Department of Chemistry, DBS (PG) College, Dehradun, Uttarakhand, India \\ *Corresponding author: bhavtoshchem@gmail.com
}

Received June 16, 2014; Revised July 21, 2014; Accepted July 27, 2014

\begin{abstract}
The water quality of Pauri District of Uttarakhand, India has been assessed during pre- and postmonsoon seasons to express the suitability of water for drinking purposes. The values of turbidity and iron exceed the permissible limit prescribed by Indian Standards for drinking purpose. Some sites were also contaminated with large number of total and fecal coliform bacteria. Piper diagrams exhibit that all water samples fall in Ca-Mg$\mathrm{HCO}_{3}$ hydrochemical facies and show the nature of carbonate hardness during both seasons. Based on the seasonal variation, the concentrations of most of the parameters considerably decreased during post-monsoon season and show the dilution effect of rain water in monsoon season. Water quality index describes the suitability of all sources for drinking purpose with 'Good' and 'Excellent' water quality during pre- and post-monsoon seasons, respectively.
\end{abstract}

Keywords: Drinking water quality, Piper diagrams, Water quality index, Uttarakhand, Pauri district, India

Cite This Article: Shweta Tyagi, Prashant Singh, Bhavtosh Sharma, and Rakesh Singh, "Assessment of Water Quality for Drinking Purpose in District Pauri of Uttarakhand, India." Applied Ecology and Environmental Sciences, vol. 2, no. 4 (2014): 94-99. doi: 10.12691/aees-2-4-2.

\section{Introduction}

In Uttarakhand, a large portion of population lives in the hilly areas and about $90 \%$ of the rural population depends upon the natural water sources for their daily water demand $[1,2]$. Due to the topography and high slops of the state, the drinking water supply department is mainly dependent on surface water sources to meet the rising demand of water. Therefore, economic, agricultural and social activities within Pauri district require urgent need to maintain the status of water sources. The water quality analysis is a most important part of hydrogeological investigations to quantify the composition of chemical characters. The factors influencing the water quality are the degree of weathering of rocks, topography of ground, seasonal variation, and discrepancy in monsoonal rainfall [3]. Besides, the rapid growth of population, higher demand of agricultural products, unplanned urbanization, over exploitation of water sources and other anthropogenic activities on the ground also led to the deterioration of surface water quality $[1,4,5]$.

The main problematic issue of hilly region is the bacterial contamination generating due to direct or indirect discharge of municipal waste in river system owing to the slope factor [6]. These coliform contaminations particularly fecal coliform, seriously affect the human health and entail the major water borne diseases such as diarrhea, cholera, typhoid, schistosomiasis etc. [7]. Water
Quality Index (WQI) is the most effective tool to convey the water quality information in the simplest form to the general public and legislative decision makers [8]. WQI transforms the large and complexed information of raw water quality data into a simplified and logical form with different categories of water quality that reflects the overall water quality status [9]. It has become a central theme of many national and international environmental agencies in various countries to determine water quality status of any source for various uses and for comparative purposes between different stations [10,11]. Numerous studies have used the various indices to predict the water quality of different regions for drinking and other uses $[12,13,14]$. Brown et al. in 1972 [12] have proposed an unambiguous method for communicating this information to everyone concerned by using simple, stable, consistent, and reproducible unit of water quality index method. Where as in 2006, Lumb et al. [13] employed the Canadian Water Quality Index to suggest the water quality of the Mackenzie-Great Bear sub-basin of Canada, which impacted by high turbidity and total (mostly particulate) trace metals due to high suspended sediment loads during the open water season.

Drinking water quality has emerged as major issue requiring immediate attention. Hence, regular monitoring of water quality is necessary to determine the pollution level of ground and surface waters. None of the agencies so far conducted any monitoring programme for quality of water resources of Pauri district of Uttarakhand. Therefore, till now no monitoring data has been generated for major drinking water sources of Pauri district. However, we have 
compared the water quality of river Alaknanda at Srinagar and river East Nayar at Satpuli in Pauri district of Uttarakhand with the water quality of river bank filtrate obtained from RBF wells established adjacent to these rivers for physico-chemical and bacteriological parameters [2]. The present study has been conducted to determine the concentration of hydrochemical constituents of drinking water sources of Pauri district in Uttarakhand state of India and compared with Indian Standards related to its suitability for drinking purposes. The study reveals the seasonal variation in water quality of selected sources during pre- and post-monsoon seasons of the year. In the study, piper diagrams indicate the presence of major ions in water sources due to the dissolution of mineral ions from rocks of mountains. Water Quality Index (WQI) describes the suitability of selected six water sources for drinking purpose and communicates the information related to water quality to the concerned citizens and policy makers.

\section{Materials and Methods}

\subsection{Study Area}

Pauri Garhwal, an important district of Uttarakhand state in India, covers an area of $5,230 \mathrm{~km}^{2}$ and situated between latitude $29^{\circ} 45^{\prime}$ to $30^{\circ} 15^{\prime} \mathrm{N}$ and longitude $78^{\circ}$ $24^{\prime}$ to $79^{\circ} 23^{\prime}$ E [15]. According to census 2011, the total population of the district has reached upto 6,86,527 [16]. Besides Alaknanda, Nayar River is the major river of the district and is one of the major tributaries of Alaknanda, which is called Nayar after the confluence of Eastern and Western Nayar at Satpuli. Average annual rainfall in the district is $2180 \mathrm{~mm}$, where about 90 percent is generally concentrated over the monsoon. Soils of the region have been formed either through pedogenetic processes or transported soils. The pedogenetic soils are formed by long duration of exposure to atmospheric factors, physical and chemical weathering and rock slides. Such types of soils are derived from granite gneissic, schistose and phyllite rocks. These soils obtained high percentage of silica from their parent body, while the soils formed from the limestone are rich in calcium carbonate. The transported soils are carried and deposited by the streams. The brown forest soil contains very high percentage of organic matter.

\subsection{Methodology}

Six major drinking water sources of Pauri district namely Srinagar (Alaknanda River) (site no.1), Satpuli (Madhuganga River) (site no.2), Buganio (Gadoli Gadhera) (site no.3), Ghodikhal (Kevru Gadhera) (site no.4), Maithana Gaon (Gazald Gadhera) (site no.5) and Kanskheit (Adwani Gadhera) (site no.6) were selected as water sampling sites (Table 1). The GPS co-ordinates were collected from each site by using GPS system (Make: Garmin, Taiwan; Model: GPSmap 76CSx) along with temperature of water (using mercury thermometer). The GPS co-ordinates with elevation above Mean Sea Level (MSL) and temperature of selected sites are summarized in Table 1.

Table 1. Description of Water Sampling Sites of Pauri District

\begin{tabular}{|l|l|l|l|l|l|}
\hline Site No. & Sampling Site (Source) & Latitude & Longitude & Elevation (in Meter) & Temperature (in ${ }^{\circ}$ C) \\
\hline 1 & Srinagar (Alaknanda River) & $30^{\circ} 13^{\prime} 12.4^{\prime \prime} \mathrm{N}$ & $78^{\circ} 47^{\prime} 53.7^{\prime \prime} \mathrm{E}$ & 526 & 21.0 \\
\hline 2 & Satpuli (Madhuganga River) & $29^{\circ} 55^{\prime} 09.0^{\prime \prime} \mathrm{N}$ & $78^{\circ} 42^{\prime} 42.0^{\prime \prime} \mathrm{E}$ & 570 & 25.5 \\
\hline 3 & Buganio (Gadoli Gadhera) & $30^{\circ} 08^{\prime} 57.5^{\prime \prime} \mathrm{N}$ & $78^{\circ} 48^{\prime} 216^{\prime \prime} \mathrm{E}$ & 1143 & 23.5 \\
\hline 4 & Ghodikhal (Kevru Gadhera) & $30^{\circ} 06^{\prime} 44.1^{\prime \prime} \mathrm{N}$ & $78^{\circ} 46^{\prime} 06.8^{\prime \prime} \mathrm{E}$ & 1561 & 22.0 \\
\hline 5 & Maithana Gaon (Gazald Gadhera) & $30^{\circ} 10^{\prime} 01.2^{\prime \prime} \mathrm{N}$ & $78^{\circ} 44^{\prime} 34.2^{\prime \prime} \mathrm{E}$ & 1320 & 08.0 \\
\hline 6 & Kanskheit (Adwani Gadhera) & $30^{\circ} 04^{\prime} 19.3^{\prime \prime} \mathrm{N}$ & $78^{\circ} 43^{\prime} 19.7^{\prime \prime} \mathrm{E}$ & 1819 & 20.5 \\
\hline
\end{tabular}
in the district through water supply department of the state (Uttarakhand Jal Sansthan) to cater the mass population of the district. Water samples were collected from each site during pre-monsoon (April-May) and post-monsoon (October-November) seasons of the year 2011. Grab sampling was preferred for sample collection.

Water samples were collected in high-density polyethylene 'Tarson' brand bottles after 2-3 times rinsing with the sample. For trace metal analysis, water samples were collected in acid-leached polyethylene bottles and preserved by adding ultra pure nitric acid $(5 \mathrm{ml} / \mathrm{l})$ to minimize the adsorption and precipitation by reducing $\mathrm{pH}$ $<2$. While for bacteriological analysis, samples were taken in sterilized Tarson bottles covered with aluminum foils. $\mathrm{pH}$ and turbidity parameters were measured on site while for other parameters, water samples were brought to the laboratory at $4^{\circ} \mathrm{C}$ in sampling box. Sample preservation and physico-chemical analysis were performed as per standard methods of APHA [17]. Colorimetric analysis was performed by UV-VIS spectrophotometer of Merck, Germany (Model: Pharo300). Metal ion concentrations [18]. All the chemicals and reagents of analytical grade were purchased from Merck, India. Analytical grade water from Millipore water purification system (Make: Millipore, USA; Model: Elix and Synergy) was used for the preparation of all standards and solutions.

\section{Results and Discussion}

The detailed discussion of analysed physico-chemical characteristics of collected water samples from Pauri district is presented under the Table 2. These results are also compared with Bureau of Indian Standard IS 10500 [19] recommended for drinking purpose.

\subsection{Turbidity and $\mathbf{p H}$}

The turbidity values fluctuated from 1.0 to 24 NTU and 7.8 to 9.8 NTU, respectively during pre- and postmonsoon seasons. Site no.1 (i.e. Srinagar) has higher 
turbidity value as 24 NTU than the permissible limit of 5 NTU during pre-monsoon season. The higher turbidity values in water sources of Pauri district has also been verified by the monitoring study of Govt. of India [20,21].
The $\mathrm{pH}$ values ranged from 7.10 to 8.26 and from 7.38 to 7.87 during pre- and post-monsoon seasons, respectively. The $\mathrm{pH}$ values in all drinking water sources were found within the recommended limit of BIS as 6.5 to 8.5.

Table 2. Hydrochemical data of water samples of Pauri district

\begin{tabular}{|c|c|c|c|c|c|c|}
\hline \multirow{2}{*}{ Parameters } & \multicolumn{2}{|l|}{ BIS Standard } & \multicolumn{4}{|c|}{ Water Quality Data } \\
\hline & Desirable limit & Permissible limit & Minimum & Maximum & Average & SD \\
\hline Turbidity, NTU & 1 & 5 & $1.0(7.8)$ & $24(9.8)$ & $9.8(8.8)$ & $7.6(0.9)$ \\
\hline $\mathrm{pH}$ & $6.5-8.5$ & No relaxation & $7.10(7.38)$ & $8.26(7.87)$ & $7.76(7.71)$ & $0.40(0.20)$ \\
\hline Total hardness, mg/l & 200 & 600 & $41(21)$ & $152(69)$ & 75 (38) & 39 (18) \\
\hline Alkalinity, mg/l & 200 & 600 & $27(18)$ & $114(52)$ & $53(32)$ & 31 (14) \\
\hline TDS, mg/l & 500 & 2000 & $68(49)$ & $236(116)$ & $119(74)$ & $59(28)$ \\
\hline Calcium, mg/l & 75 & 200 & $9.45(4.45)$ & $36(15)$ & $18(10)$ & $9.3(4.0)$ \\
\hline Magnesium, mg/l & 30 & 100 & $4.28(1.8)$ & $15(7.39)$ & $7.30(3.35)$ & $3.9(2.1)$ \\
\hline Sodium, mg/l & - & - & $2.86(2.62)$ & 3.87 (6.73) & $3.22(4.62)$ & $0.40(1.5)$ \\
\hline Potassium, mg/l & - & - & $0.88(0.39)$ & $1.72(2.43)$ & $1.17(1.18)$ & $0.30(0.84)$ \\
\hline Chloride, mg/l & 250 & 1000 & $12(08)$ & $18(12)$ & $15(10)$ & $2.40(1.7)$ \\
\hline Fluoride, mg/l & 1.0 & 1.5 & $0.34(0.05)$ & $0.43(0.23)$ & $0.40(0.14)$ & $0.04(0.10)$ \\
\hline Sulphate, mg/l & 200 & 400 & ND (ND) & $18(12)$ & $6(3)$ & $8.8(4.8)$ \\
\hline Nitrate, mg/l & 45 & No relaxation & $0.4(0.6)$ & $3.4(1.4)$ & $1.4(0.9)$ & $1.1(0.3)$ \\
\hline Iron, mg/l & 0.3 & No relaxation & $0.104(0.073)$ & $0.364(1.777)$ & $0.218(0.514)$ & $0.09(0.70)$ \\
\hline TC, Colonies/100ml & Absent & Absent & Absent (Absent) & $160(09)$ & $48(1.5)$ & $66(3.7)$ \\
\hline FC, Colonies/100ml & Absent & Absent & Absent (Absent) & 75 (Absent) & 13 (Absent) & 31 (Absent) \\
\hline
\end{tabular}

ND: not detected; SD: standard deviation; The values given in parenthesis indicate post-monsoon data.

\subsection{Total Hardness and Alkalinity}

The range of total hardness were found in between 41 to $152 \mathrm{mg} / \mathrm{l}$ and 21 to $69 \mathrm{mg} / \mathrm{l}$, respectively during preand post-monsoon seasons for all the samples falling within the desirable limit of $200 \mathrm{mg} / \mathrm{l}$ of BIS. Alkalinity values in the analyzed water samples were obtained from 27 to $114 \mathrm{mg} / \mathrm{l}$ and 18 to $52 \mathrm{mg} / \mathrm{l}$, respectively during preand post-monsoon seasons. The results show that all concentrations were found to be within the desirable limit of $200 \mathrm{mg} / \mathrm{l}$.

\subsection{Total Dissolved Solids (TDS)}

TDS values fluctuated from 68 to $236 \mathrm{mg} / \mathrm{l}$ and 49 to $116 \mathrm{mg} / \mathrm{l}$, respectively in pre- and post-monsoon seasons. TDS content in all the samples were well within the desirable range of $500 \mathrm{mg} / \mathrm{l}$ of BIS.

\subsection{Calcium and Magnesium}

The calcium contents in water samples ranged within 9.45 to $36 \mathrm{mg} / \mathrm{l}$ during pre-monsoon season and 4.45 to 15 $\mathrm{mg} / \mathrm{l}$ during post-monsoon season. The magnesium content varied from 4.28 to $15 \mathrm{mg} / \mathrm{l}$ and 1.80 to $7.39 \mathrm{mg} / \mathrm{l}$, respectively for pre- and post-monsoon seasons. The results indicate that no site exceeded the concentration of calcium and magnesium from their desirable limits as per BIS 10500 of 75 and 30 mg/l, respectively.

\subsection{Sodium and Potassium}

The values of sodium were quite lower in analysed water samples, which fluctuated from 2.86 to $3.87 \mathrm{mg} / \mathrm{l}$ and 2.62 to $6.73 \mathrm{mg} / \mathrm{l}$, respectively in pre- and postmonsoon seasons. The sodium values in all samples were well within the prescribed limit of WHO as $20 \mathrm{mg} / \mathrm{l}$. The potassium ion concentration oscillated within 0.88 to 1.72 $\mathrm{mg} / \mathrm{l}$ during pre-monsoon season and 0.39 to $2.43 \mathrm{mg} / \mathrm{l}$ during post-monsoon season. BIS and WHO have not prescribed any limit for potassium ions in drinking water but it is useful for total ionic balance as well as important nutrient for human body. The seasonal variations for potassium ion were negligible during study.

\subsection{Chloride and Fluoride}

The chloride concentrations were found from 12 to 18 $\mathrm{mg} / \mathrm{l}$ and 8 to $12 \mathrm{mg} / \mathrm{l}$ in analysed samples during pre- and post-monsoon seasons. Fluoride concentration ranged from 0.34 to 0.43 and 0.05 to $0.23 \mathrm{mg} / \mathrm{l}$, respectively during pre- and post-monsoon seasons. No sample exceeded the desirable limit of $250 \mathrm{mg} / \mathrm{l}$ for chloride and $1.0 \mathrm{mg} / \mathrm{l}$ for fluoride.

\subsection{Nitrate and Sulphate}

The values of nitrate were confined between 0.4 to 3.4 and 0.6 to $1.4 \mathrm{mg} / \mathrm{l}$, respectively during pre- and postmonsoon seasons. Nitrate concentration in water samples of all sites were well within the prescribed limit of $45 \mathrm{mg} / \mathrm{l}$. The sulphate concentration fluctuated in a limited range of ND (not detected) to $18 \mathrm{mg} / \mathrm{l}$ in pre-monsoon season and $\mathrm{ND}$ to $12 \mathrm{mg} / \mathrm{l}$ in post-monsoon season. The collected concentrations of sulphate were much lower than the desirable limit of sulphate as $200 \mathrm{mg} / \mathrm{l}$.

\subsection{Iron}

In the drinking water samples, the iron content was from 0.104 to $0.364 \mathrm{mg} / \mathrm{l}$ and 0.073 to $1.777 \mathrm{mg} / \mathrm{l}$, respectively during pre- and post-monsoon seasons. The maximum concentrations of iron as $0.364 \mathrm{mg} / \mathrm{l}$ and 1.777 $\mathrm{mg} / \mathrm{l}$ were recorded at Srinagar (Alaknanda River) sampling site no.1 during both pre- and post-monsoon seasons. These concentrations of iron were higher than the permissible limit of $0.3 \mathrm{mg} / \mathrm{l}$, which is further confirmed by another study [21]. 


\subsection{Bacteriological (Total Coliform and Fecal Coliform) Analysis}

In the bacteriological assessment of water sources of study area, total coliform were recorded from absent to 160 colonies $/ 100 \mathrm{ml}$ during pre-monsoon season. While in post-monsoon season, these organisms were recorded as 9 colonies/100ml at Srinagar (Alaknanda River) sampling location. Fecal coliform counts were found as 75 colonies/100ml only at Srinagar sampling site during premonsoon season, while in post-monsoon season, all sites were free from any fecal contamination. In the study, higher total and fecal coliform contaminations were noted only at Srinagar sampling site (Site no.1).

\section{Water Quality Classification Using Piper Trilinear Diagram}

Piper trilinear diagrams (Piper, 1944) were prepared to classify the water quality of selected sources of study area [22]. The diagram classified the hydrochemical facies in account of prominent ions contributed the water quality. These diagrams graphically represent the chemical equilibrium between cations $\left(\mathrm{Ca}^{2+}, \mathrm{Mg}^{2+}, \mathrm{Na}^{+}\right.$and $\left.\mathrm{K}^{+}\right)$and anions $\left(\mathrm{Cl}^{-}, \mathrm{SO}_{4}{ }^{2-}, \mathrm{CO}_{3}{ }^{2-}\right.$ and $\left.\mathrm{HCO}_{3}{ }^{-}\right)$in water samples and also describe the presence of main contributor ions and chemical reactions taking place in the water. The diagram composed of two lower triangles of cations and, anions and middle quadrilateral. Quadrilateral or diamond shape indicates the combined distribution of both ions (cations and anions) and final water type of sources. Such diagrams may describe various hydrochemical processes like base cation exchange, cement pollution, mixing of natural waters, sulfate reduction, saline water (end-product water) and other related hydrochemical problems.

In present study, water quality of selected sites during pre- and post-monsoon seasons has been characterized using Piper diagrams (Figure 1). These diagrams represent that water quality of all selected sources is predominantly influenced by $\mathrm{Ca}^{+2}, \mathrm{Mg}^{+2}$ and $\mathrm{HCO}_{3}{ }^{-}$ions i.e. Ca-Mg$\mathrm{HCO}_{3}$ hydrochemical facies during both pre- and postmonsoon seasons. These plots represent the equal dominance of alkaline earth metals and weak acid and thus water quality shows the nature of carbonate hardness.

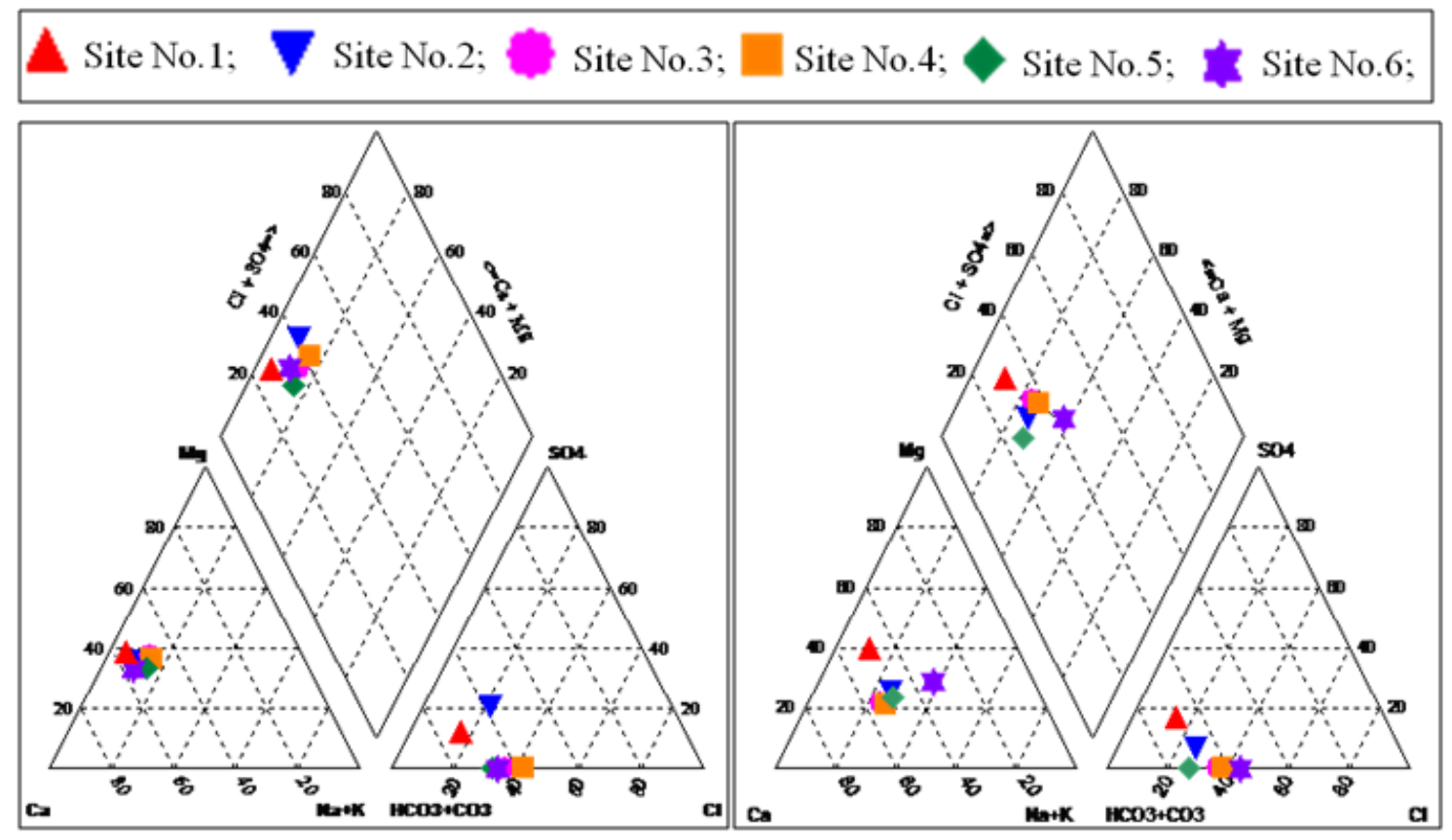

Pre-monsoon season

Post-monsoon season

Figure 1. Piper diagram showing water quality classification of study area

\section{Suitability of Water for Drinking Purpose Using Water Quality Index}

Weight Arithmetic Water Quality Index Method was employed in determining the water Quality Index for assessing the suitability of water sources for drinking purpose. Such WQI has been extensively used for surface and groundwater quality assessment, mainly in different regions of India and also outside [9,23,24,25]. The index classifies the water quality based on the purity of sample by using the most commonly measured water quality parameters. This index was computed by using the following steps:
In the first step, water quality parameters including TDS, $\mathrm{HCO}_{3}, \mathrm{Cl}, \mathrm{SO}_{4}, \mathrm{NO}_{3}, \mathrm{~F}, \mathrm{Ca}, \mathrm{Mg}, \mathrm{Na}$ and $\mathrm{K}$ were selected to summarize the water quality, which indicate the considerable impact in the regions.

In the second step, quality rating or subindex $\left(\mathrm{q}_{\mathrm{i}}\right)$ is computed for each of the parameter by using the given expression:

$$
\mathrm{q}_{\mathrm{i}}=\left(\mathrm{V}_{\text {actual }}-\mathrm{V}_{\text {ideal }}\right) /\left(\mathrm{V}_{\text {standard }}-\mathrm{V}_{\text {ideal }}\right) \times 100
$$

Where, $\mathrm{V}_{\text {actual }}$ is the estimated value of $\mathrm{i}^{\text {th }}$ parameter in the analysed water sample; $\mathrm{V}_{\text {ideal }}$ is the ideal value of this parameter in pure water. The ideal value is zero for all parameters except $\mathrm{pH}=7.0$ and $\mathrm{V}_{\text {standard }}$ is the 
recommended standard value of $i^{\text {th }}$ parameter given in Table 2.

In the third step, the unit weight $\left(\mathrm{W}_{\mathrm{i}}\right)$ for each water quality parameter was determined by using the following formula:

$$
\mathrm{W}_{\mathrm{i}}=\mathrm{K} / \mathrm{S}_{\mathrm{i}}
$$

Where, $S_{i}$ is standard value of $i^{\text {th }}$ parameter recommended by $\mathrm{BIS} ; \mathrm{K}$ is the proportionality constant which is calculated by using the following equation:

$$
\mathrm{K}=1 /\left(\Sigma 1 / \mathrm{S}_{\mathrm{i}}\right)
$$

In the final step, the overall WQI is calculated by using following formula:

$$
\mathrm{WQI}=\Sigma \mathrm{q}_{\mathrm{i}} \mathrm{W}_{\mathrm{i}} / \Sigma \mathrm{W}_{\mathrm{i}}
$$

The water quality ratings on the basis of index value for this WQI are summarized in Table 3.

Table 3. Water quality rating and index values

\begin{tabular}{|l|l|l|}
\hline WQI value & Water quality rating & Grading \\
\hline $0-25$ & Excellent water quality & A \\
\hline $26-50$ & Good water quality & B \\
\hline $51-75$ & Poor water quality & C \\
\hline $76-100$ & Very poor water quality & D \\
\hline$>100$ & Unsuitable water quality & E \\
\hline
\end{tabular}

Table 4. WQI values and relative description of water samples

\begin{tabular}{|l|l|l|l|l|l|l|l|}
\hline \multirow{2}{*}{ S. No. } & \multirow{2}{*}{ Sampling site } & \multicolumn{3}{|c|}{ Pre-monsoon season } & \multicolumn{3}{c|}{ Post-monsoon season } \\
\cline { 3 - 8 } & & WQI value & Description & Grade & WQI value & Description & Grade \\
\hline 1 & Srinagar & 33.74 & Good & B & 22.51 & Excellent & A \\
\hline 2 & Satpuli & 36.42 & Good & B & 10.06 & Excellent & A \\
\hline 3 & Buganio & 30.52 & Good & B & 5.31 & Excellent & A \\
\hline 4 & Ghodikhal & 35.92 & Good & B & 19.50 & Excellent & A \\
\hline 5 & Maithana Gaon & 37.75 & Good & B & 10.06 & Excellent & A \\
\hline 6 & Kanskheit & 37.98 & Good & B & 11.93 & Excellent & A \\
\hline
\end{tabular}

The results of WQI method during pre- and postmonsoon seasons are summarized in Table 4 . The values of WQI ranged from 30.52 to 37.98 during pre-monsoon season and from 5.31 to 22.51 in post-monsoon season. All water samples in pre-monsoon season indicate the 'Good' water quality with 'B' grade, whereas in postmonsoon season, all samples were of 'Excellent' water quality with 'A' grade water. The lowering of results in post-monsoon season shows the dilution effect of rain water in monsoon season. Overall results conclude that water samples of all sites of Pauri district were found suitable for drinking purpose during both pre- and postmonsoon seasons.

\section{Conclusion}

Major drinking water sources in Pauri district are surface water sources. The quality of surface water varies from one season to another season due to the heavy rainfall of the region. The water quality of major surface water sources of study area has been assessed for drinking uses by analyzing various physico-chemical and bacteriological parameters during pre- and post-monsoon seasons. The ranges of turbidity and iron are significantly varying in surface water and exceed the desirable as well as permissible limits of BIS specification. Coliform contamination in surface water is also high. Piper diagrams indicate the dominancy of calcium, magnesium and bicarbonate ions in all the selected samples i.e. Ca$\mathrm{Mg}-\mathrm{HCO}_{3}$ water type. Water Quality Index (WQI) reveals the 'Good' and 'Excellent' water quality during pre- and post-monsoon seasons, respectively. The results of the study confirm the suitability of all selected water sources for drinking purposes. But, regular monitoring is required to determine the pollution load with follow up treatment of water to improve the water quality, which is being used for drinking purpose.

\section{Acknowledgement}

The authors are thankful to the Uttarakhand State Council for Science and Technology (UCOST); Uttarakhand Jal Sansthan (UJS), Dehradun; WTI, DST New Delhi and FIST/DST New Delhi in association with DAV (PG) College, Dehradun for financial assistance provided for this work. The authors are also thankful for Uttarakhand Science Education \& Research Centre (USERC), Dehradun for technical support.

\section{References}

[1] Jain CK, Bandyopadhyay A, Bhadra A. 2010. Assessment of ground water quality for drinking purpose, District Nainital, Uttarakhand, India. Environment Monitoring Assessment, 166, 663-676.

[2] Tyagi S, Dobhal R, Kimothi PC, Adlakha LK, Singh P, Uniyal DP. 2013. Studies of river water quality using river bank filtration in Uttarakhand, India. Water Quality Exposure and Health, 5, 139148.

[3] Singh P, Tyagi S, Dobhal R, Singh R, Seth R, Mohan M. 2012. Evaluation of water quantity and quality status of drinking water sector of Uttarakhand, India. Analytical Chemistry Letters, 2(3), 198-205.

[4] Gupta VK, Dobhal R, Nayak A, Agarwal S, Uniyal DP, Singh P, Sharma B, Tyagi S, Singh S. 2012. Toxic metal ions in water and their prevalence in Uttarakhand, India. Water Science and Technology: Water Supply, 12, 773-782.

[5] Sharma B, Uniyal DP. 2013. Water Resources, In Uttarakhand: State of the Environment Report, Edited by Dr. Rajendra Dobhal, Publisher M/s Bishen Singh Mahendra Pal Singh and Uttarakhand State Council for Science \& Technology, Dehradun. pp. 166-209.

[6] Rawat V, Jha SK, Bag A, Singhai M, Rawat CM. 2012. The bacteriological quality of drinking water in Haldwani block of Nainital district, Uttarakhand, India. Journal of Water and Health, 10(3), 465-470.

[7] Mishra VK, Singh, AK, 2008. Institutionalizing community led action for sanitary survey. $33^{\text {rd }}$ WEDC International Conference, Accra, Ghana.

[8] Babaei Semiromi F, Hassani AH, Torabian A, Karbassi AR, Hosseinzadeh Lotfi F. 2011. Evolution of a new surface water 
quality index for Karoon catchment in Iran. Water Science and Technology, 64(12), 2483-2491.

[9] Tyagi S, Sharma B, Singh P, Dobhal R. 2013a. Water quality assessment in terms of water quality index. American Journal of Water Resources, 1, 34-38.

[10] Khan F, Husain T, Lumb A. 2003. Water quality evaluation and trend analysis in selected watersheds of the Atlantic region of Canada. Environment Monitoring Assessment, 88(1-3), 221-248.

[11] Liou SM, Liens S, Wang SH. 2004. Generalized water quality index for Taiwan.Environment Monitoring Assessment, 96(1), 3552.

[12] Brown RM, McClelland NI, Deininger RA, O’Connor MF, 1972, A water quality index-Crashing the psychological barrier. Indicators of Environmental Quality, 1(1), 173-178.

[13] Lumb A, Halliwell D, Sharma T. 2006. Application of CCME water quality index to monitor water quality: a case of the Mackenzie river basin, Canada. Environment Monitoring Assessment, 113, 411-429.

[14] Abdulwahid SJ. 2013. Water quality index of Delizhiyan springs and Shawrawa River within Soran District, Erbil, Kurdistan Region of Iraq. Journal of Applied Environmental and Biological Sciences, 3(1), 40-48.

[15] Pauri Garhwal-Uttarakhand. 2014. Welcome to the District of Pauri Garhwal. Available at: http://pauri.nic.in accessed $11 / 06 / 2014$.

[16] Census of India. 2011. Provisional population totals, Paper 2, Volume 1, Rural and urban distribution, Uttarakhand Series 6.
[17] Eaton AD, Clesceri LS, Rice EW, Greenberg AE, 2005. Standard Methods for the Examination of Water and Wastewater, $21^{\text {st }}$ ed. American Public Health Association, Washington, DC, USA.

[18] Sharma B, Tyagi S. 2013. Simplification of metal ion analysis in fresh water samples by atomic absorption spectroscopy for laboratory students. Journal of Laboratory Chemical Education, 1(3), 54-58.

[19] BIS (Bureau of Indian Standards). 2012. Specification for drinking water IS 10500: 2012, New Delhi, India.

[20] MIS 2009. Integrated Management Information System Department of Drinking Water Supply, Ministry of Rural Development, India.

[21] IMIS 2012. Integrated Management Information System. Department of Drinking Water Supply, Ministry of Rural Development, India.

[22] Piper AM 1944. A graphic procedure in the geochemical interpretation of water analyses. Transactions - American Geophysical Union, 25, 914-928.

[23] Tiwari TN, Mishra M. 1985. A preliminary assignment of water quality index to major Indian rivers. Indian Journal of Environmental Protection, 5(4), 276-279.

[24] Behmanesh A, Feizabadi Y. 2013. Water quality index of Babolrood River in Mazandaran, Iran. International Journal of Agriculture and Crop Sciences, 5(19), 2285-2292.

[25] Radmanesh F, Zarei H, Salari M. 2013. Water quality index and suitability of water of Gotvand Basin at District Khuzestan, Iran. International Journal of Agronomy and Plant Production, 4(4), 707-713. 